Eur. J. Clin. Chem. Clin. Biochem.

Vol. 29, 1991, pp. 429-432

(C) 1991 Walter de Gruyter \& Co. Berlin - New York

\title{
Effect of Ascaris lumbricoides Infection on Brain Enzymes
}

\author{
By S. H. Doss ${ }^{1}$ and N. R. Tadros ${ }^{2}$ \\ 1 Hormone Department, National Research Center, Cairo, Egypt \\ 2 Faculty of Science, Mansoura University, Mansoura, Egypt
}

(Received June 5/October 23, 1990)

Dedicated to the memory of Professor Dr. B. Helferich

Summary: In guinea pigs infected with Ascaris lumbricoides, the brain glutamine synthetase showed insignificant changes compared with uninfected controls, whereas the brain histidine decarboxylase was increased.

\section{Introduction}

In continuation of our work on enzymology $(1-3)$ and in an attempt to apply published data $(4,5)$ in the field of parasitology, we studied the effect of Ascaris lumbricoides infection on glutamine synthetase and histidine decarboxylase in guinea pig brain (6).

Glutamine synthetase (EC 6.3.1.2) catalyses the formation of glutamine from glutamate and ammonia coupled with the breakdown of ATP to ADP and phosphate. In the presence of ATP, glutamate and $\mathrm{Mg}$, but in the absence of ammonia the enzyme forms a complex containing glutamate, $\mathrm{ADP}$ and phosphate; with ammonia, this complex forms glutamine, ADP, phosphate and free enzyme. The presence of ATP is necessary for the enzyme to bind glutamate, and for the reverse reaction ADP is required for the binding glutamine (7):

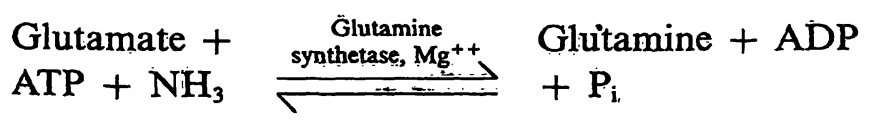

When hydroxylamine is substituted for ammonia, $\gamma$ glutamylhydroxamate is formed at about the same rate (7).

In a study with ${ }^{18} \mathrm{O}$-labelled glutamate, it has been shown that ${ }^{18} \mathrm{O}$ appears in the phosphate produced, confirming the intermediate formation of glutamyl phosphate (8). This study indicated that the essential reaction takes place within a quaternary complex, a conclusion confirmed by the studies of Hartman \& Buchanan (9) and Gass \& Meiter (10).

Histidine decarboxylase (EC 4.1.1.22) is a pyridoxal phosphate enzyme, which converts histidine to histamine in the brain by decarboxylation (11), and which is involved in some types of rashes and allergies in other parts of the body. Histamine is an important vasodilator which is released in certain tissues as a result of allergic hypersensitivity or inflammation.

Infection with Ascaris lumbricoides can be summarized as follows: When fully embryonated eggs are swallowed, they hatch in the duodenum and then undergo an excursion in the body before returning to settle down in the intestine and grow to adulthood. The larvae (length $260 \mu \mathrm{m}$, diameter $14 \mu \mathrm{m}$ ) first penetrate the wall of the duodenum and enter blood or lymphatic vessels to be carried to the liver, heart and then into the pulmonary circulation. They are filtered out by the capillaries of the lung, from where they break through into the alveoli. There they grow and moult, and after about 10 days migrate through the respiratory passages to reach the oesophagus and normally once again the small intestine. Two or three months after ingestion of infectious eggs by the host, the resulting mature worms commence egg-laying in the intestine (12).

We studied the brain enzymes during the first 80 days of infection, because during this period the larvae are migrating in the blood and lymphatic vessels, reaching 
the liver, heart and the pulmonary circulation. It is therefore expected that any effect on brain enzymes will be greatest at this time, rather than later when the parasites have settled in the intestine and started to lay eggs. We have already reported (13) decreased albumin and increased globulins during the first 80 days of infection.

\section{Materials and Methods}

Guinea pigs weighing $350-400 \mathrm{~g}$ were used. Animals were divided into two groups. One group was infected with Ascaris lumbricoides. The second group served as control. Every 10 days, three infected animals and three control animals were dissected to confirm the presence of the larvae $(6-8)$, then the brains were collected. Brain homogenates were prepared as $2 \mathrm{~g}$ brain in $100 \mathrm{ml}$ cold saline using an all glass homogenizer. The supernatant obtained after centrifugation was used for the enzyme assay. Centrifugation was carried out with a Beckman centrifuge Model TJ-6 at $3000 \mathrm{~g}$ for $5 \mathrm{~min}$.

\section{Method of infection}

Eggs of $A$. lumbricoides were obtained from the distal third of the uteri of freshly collected adult female worms. After washing with distilled water several times the eggs were incubated in 25 $\mathrm{g} / \mathrm{l}$ potassium dichromate at $26-28^{\circ} \mathrm{C}$ for two weeks. The eggs were daily agitated every twelve hours, with a shaker at low speed, to avoid adherence to the wall of the container. Microscopic examination was continued daily to detect the formation of the second stage movable larvae. The number of eggs present in each drop was counted microscopically to determine the volume of distilled water containing 3000 eggs with the highest number of the 2 nd stage larvae. Between 5 and $8 \mathrm{ml}$ of distilled water containing infective embryonated eggs of $A$. lumbricoides were administered orally to partially anaesthetized (ether, Merck) guinea pigs which had been denied water for the previous 10 hours. The faeces of the animals were examined for the unembryonated eggs or the larval eggs which have passed undigested. After 4-6 days no eggs were observed in the faeces of the animals. All the dissected guinea pigs contained 6-8 worms.

Guinea pigs aged 40-50 days were chosen, in order to profit from the immune response present in this host.

\section{Enzyme assays}

Glutamine synthetase (EC 6.3.1.2)

The activity of this enzyme was determined by the method reported by Krishnaswani et al. (7), in which the enzymatic activity was determined in a reaction mixture consisting of 50 $\mu \mathrm{mol}$ of Tris- $\mathrm{HCl}$ buffer $\mathrm{pH} 7,7.25 \mu \mathrm{mol}$ of $L$-glutamate, 100 $\mu \mathrm{mol}$ of hydroxylamine hydrochloride, $10 \mu \mathrm{mol}$ of ATP and enzyme in a final volume of $1 \mathrm{ml}$. All the reagents were added at $0^{\circ} \mathrm{C}$ and immediately after the addition of ATP the reaction vessels were placed at $37^{\circ} \mathrm{C}$. After $15 \mathrm{~min}$ at $37^{\circ} \mathrm{C}$ the reaction was stopped by addition of $1.5 \mathrm{ml}$ of a solution containing 0.37 mol $\mathrm{FeCl}_{3}, 0.67 \mathrm{~mol} / 1$ and $0.2 \mathrm{ml}$ trichloroacetic acid. The absorbance was measured at $535 \mathrm{~nm}$.

The enzyme unit was defined as the amount of enzyme that catalyses the synthesis of $1 \mu \mathrm{mol}$ of $\alpha$-glutamylhydroxamate under the specified conditions. The specific activity was expressed as $\alpha$-glutamyl-hydroxamate synthesized ( $\mu \mathrm{mol} / \mathrm{min} \cdot \mathrm{mg}$ protein).

\section{Histidine decarboxylase (EC 4.1.1.22)}

The enzyme activity was determined by following the method of Werle et al. (14) and determining the remaining substrate (histidine) by the method of Mehler et al. (15). The diazotized colour was measured at $550 \mathrm{~nm}$.

$\cdot 1$

Statistical analysis

Student's t-test was used for statistical analysis.

\section{Results}

Table 1 shows the glutamine synthetase activity in the brain of the infected guinea pigs and in the control animals. No significant differences were observed up to 80 days of infection (fig. 1).

Tab. 1. Mean glutamine synthetase (EC 6.3.1.2) activities in the brains of infected and control guinea pigs (average \pm standard deviation)

\begin{tabular}{lll}
\hline $\begin{array}{l}\text { Duration of } \\
\text { infection (days) }\end{array}$ & $\begin{array}{l}\text { Control } \\
\mu \mathrm{mol} / \mathrm{mg} \cdot \mathrm{min}\end{array}$ & $\begin{array}{l}\text { Infected } \\
\mu \mathrm{mol} / \mathrm{mg} \cdot \min \end{array}$ \\
\hline 10 & $0.150 \pm 0.008$ & $0.151 \pm 0.007$ \\
20 & $0.155 \pm 0.007$ & $0.153 \pm 0.007$ \\
30 & $0.156 \pm 0.007$ & $0.155 \pm 0.007$ \\
40 & $0.156 \pm 0.007$ & $0.155 \pm 0.006$ \\
50 & $0.157 \pm 0.008$ & $0.156 \pm 0.007$ \\
60 & $0.152 \pm 0.007$ & $0.155 \pm 0.006$ \\
70 & $0.152 \pm 0.009$ & $0.153 \pm 0.007$ \\
80 & $0.156 \pm 0.005$ & $0.153 \pm 0.005$ \\
\hline
\end{tabular}

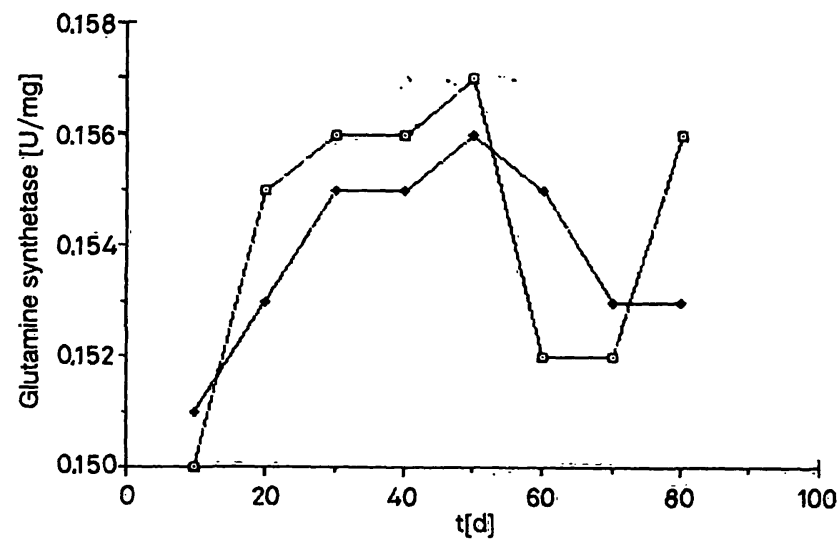

Fig. 1. Mean glutamine synthetase in the brains of infected guinea pigs.

$-\square-$ control

- - infected

Table 2 shows the histitine decarboxylase activity in the brain of the infected guinea pigs compared with the control animals. A significant increase was observed in the infected animals, starting 10 days after infection, and continuing until 30 days. At 40 days after infection,the increase persists but is of decreased magnitude, and it is still apparent after 80 days of infection (fig. 2). 
Tab. 2. Mean histidine decarboxylase (EC 4.1.1.22) activity in the brains of infected and control guinea pigs (average \pm standard deviation)

\begin{tabular}{lll}
\hline $\begin{array}{l}\text { Duration of } \\
\text { infection (days) }\end{array}$ & $\begin{array}{l}\text { Control } \\
\mu \mathrm{mol} / \mathrm{mg} \cdot \mathrm{min}\end{array}$ & $\begin{array}{l}\text { Infected } \\
\mu \mathrm{mol} / \mathrm{mg} \cdot \mathrm{min}\end{array}$ \\
\hline 10 & $1.730 \pm 0.012$ & $1.737 \pm 0.014$ \\
20 & $1.734 \pm 0.009$ & $1.746 \pm 0.007$ \\
30 & $1.740 \pm 0.012$ & $1.888 \pm 0.006$ \\
40 & $1.746 \pm 0.014$ & $1.790 \pm 0.007$ \\
50 & $1.742 \pm 0.012$ & $1.780 \pm 0.009$ \\
60 & $1.734 \pm 0.012$ & $1.760 \pm 0.006$ \\
70 & $1.742 \pm 0.009$ & $1.762 \pm 0.007$ \\
80 & $1.741 \pm 0.009$ & $1.760 \pm 0.007$ \\
\hline
\end{tabular}

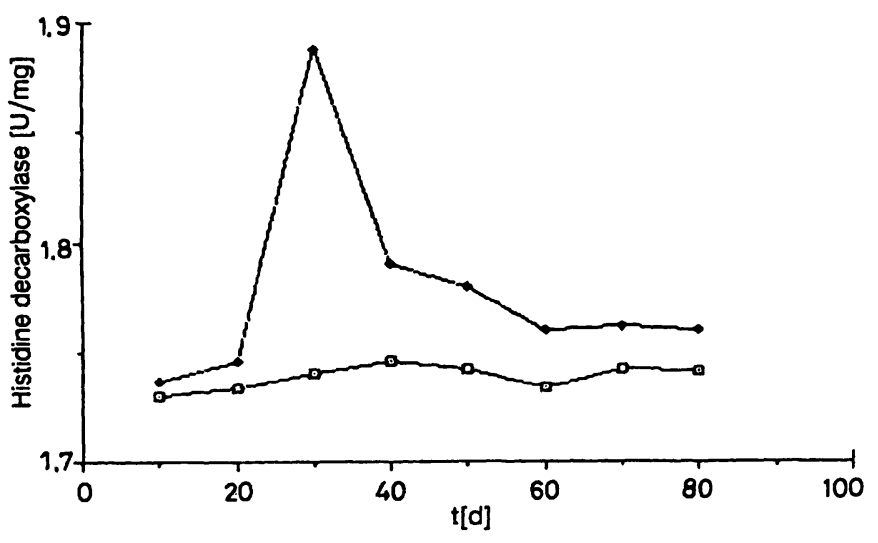

Fig. 2. Mean histidine decarboxylase in the brains of infected guinea pigs.

$-\square-$ control

- - infected

\section{Discussion}

We chose the 80 days following infection as the suitable period of study, because during this time the larvae are migrating in the blood and lymphatic tissues and their effect will be maximal on the brain enzymes. In contrast, when the larvae were established in the intestine, the activities of the brain enzymes showed no significant differences from those of the controls.

The absence of marked changes in the brain glutamine synthetase activity of the infected guinea pigs compared with controls, shows that the larvae produce no or very little toxic ammonia, and there is therefore no need for an increase of this enzyme for detoxification purposes.

On the other hand, 10 days after infection, histidine decarboxylase showed a significant increase, reached a maximum after 30 days and still apparent after 80 days. This steady increase reflects the conversion of histidine to histamine in the brain.

Histidine decarboxylase is induced by a variety of irritants and systemic stressors, including injury, infections and endotoxins (17). This steady increase in histidine decarboxylation may explain the sensitization phenomena in humans, including rashes, eye pain, asthma, insomnia and restlessness, which result as allergic responses to metabolites produced by the larvae. The response is at first acute (due to the migration of the larvae in the host organs), then mild but higher than the control, due to theft of nourishment and malnutrition, resulting in poor development in small children $(18,19)$.

Also, the steady increase in histidine decarboxylation may be due to the immunological reaction of the host against the worm, as histidine forces the leukocyte destinction.*)

It has been declared (20) that asthma and urticaria may continue during the intestinal phase of ascariasis, which may be correlated with the continued increase in histidine decarboxylase in comparison with the control, even 80 days after the onset of infection.

To confirm the significance of the small increase in histidine decarboxylase, another study is being conducted using $\left[1-{ }^{14} \mathrm{C}\right]$ histidine for the determination of enzyme activity.

\section{Acknowledgement}

The authors thank Dr. med. M. Assaad and Dr. med. N. Anis for interest and valuable discussions.

*) The authors thank one of the referees who drew their attention to this point.

\section{References}

1. Barker, S. A., Cho Tun, H., Doss, S. H., Gray, C. J. \& Kennedy, J. F. (1971) Preparation of cellulose. Carbohyd. Res. 17, $471-474$.

2. Barker, S. A., Doss, S. H., Gray, C. J., Kennedy, J. F. \& Stacey, M. (1971) $\beta$-D-Glucosidase chemically bound to microcrystalline cellulose. Carbohyd. Res. 20,1-7.

3. Doss, S. H. \& Müller, W. M. (1971) Infrared absorption spectra of anomers of $\beta$-D-glucopyranose derivatives. Aust. J. Chem. 24, 2711-2715.

4. Helferich, B. \& Doss, S. H. (1972) Synthese zweier neuer Sultame. Liebigs Ann. Chem. 756, 170-172.

5. Doss, S. H., Selim, N. L. \& Abu-Ouf, A. M. (1974) Synthesis of xanthene analogues via Stobbe condensation. Egypt. J. Bilh. 1, 239-247.

6. Helferich, B. (1933) Glucosides, British Patent, 394,195, June 22 (1933)

cf. also

Helferich, B. \& Winkler, S. (1933) Über Emulsin IV. Der 
Einfluß von Formalin auf die $\beta$-glucosidatische und $\beta$ galaktosidatische Wirkung des Emulsins. Hoppe-Seyler's Z. Physiol. Chem. 221, 98-100.

7. Krishnaswamy, P. R., Pamiljans, V. \& Meister, A. (1962) Mechanism of glutamine synthesis: evidence for the formation of enzyme-bound activated glutamic acid. J. Biol. Chem. 237, 2932-2940.

8. Boyer, P. D., Koeppe, O. J. \& Luchsinger, W. W. (1956) Direct $O$ transfer in enzymic synthesis coupled to adenosine triphosphate degradation. J. Amer. Chem. Soc. 78, 356360.

9. Hartman, S. C. \& Buchanan, J. M. (1958) Biosynthesis of the purines XXII, 2-amino-N-ribosylacetamide-5-phosphate kinosynthase. J. Biol. Chem. 233, 456-461.

10. Gass, J. D. \& Meiter, A. (1970) Computer analysis of the active site of glutamine synthetase. Biochemistry 9,13801384.

11. Frisell, W. R. (1982) Human biochemistry, Mac Millan Publishing Co. Toronto, London, p. 266.

12. Markell, E. K. \& Voge, M. (1990) Medical parasitology, $4^{\text {th }}$ ed. Saunders Company, p. 240.
13. Doss, S. H. \& Tadros, N. R. (1985) Plasma protein electrophoretic pattern in patients infected with Ascaris lumbricoides. Al-Hakeem 18, 24-25.

14. Werle, E. \& Heitzer, K. (1938) Histidine carboxylase. Biochem. Z. 299, $240=244$.

15. Mehler, A. H., Tabor, H. \& Bauer, H. (1953) Oxidation of histamine to imidazole acetic acid. J. Biol. Chem. 197, $375-480$.

16. Snatzke, G. \& Doss, S. H. (1972) Chiroptical properties of amino acid sultam derivatives. Tetrahedron $28,2539-2544$.

17. David, D. J. (1989) Studies on the histidine decarboxylase operon of lactobacillus 30A, Diss. Abstr. Int. B. 51, 716, cf. Chem. Abs. 113, $225392 \mathrm{~F}$.

18. Schmidt, G. D. \& Roberts, L. S. (1977) Foundations of parasitology, Mosby company, Saint Louis, p. 459.

19. Doss, S. H. \& Mobarak, S. (1980) Cultivation of parasites in vitro. Zanco 6,131-134.

20. Chacko, D. D. (1970) Intestinal parasites and asthma. New Engl. J. Med. 283, $101=104$.

Prof. Dr. S. H. Doss

Hormone Department

National Research Centre

Dokki

Cairo

Egypt 